\title{
DOE SUCCESS STORIES: THE ENERGY MISSION IN THE MARKETPLACE
}

Published by: DOE Office of Science Policy 5/95

Contact person: Bob Marley, Director of Office of Science Policy, (202) 586-3900

- DOE Success Stories: The Energy Mission in the Marketplace

- Energy Mission

- Role of Federal R\&D

- What Successes

- Improved R\&D

- Economic Successes

- R\&D Management Principles

- R\&D Considerations

- Deficit Reduction or Revenue Enhancement

- Increasing Energy Efficiency

- Building Technologies

- Fluorescent Lamp Electronic Ballasts

- Advanced Energy Efficient Windows

- Sulfur Lamp

- Computerized Analytical Tool for Energy Efficient Building Design

- High Efficiency Refrigerator Freezer Compressor

- Flame Retention Head Oil Burner

- Flame Quality Indicator

- Compact Fluorescent Lamps with Convective Venting

- Softdesk Energy Building Software

- Appliance Efficiency Standards

- Transportation Technologies

- Ceramic Regenerator Matrix Catalytic Exhaust Converters for Automobiles and Heavy-Duty Engines

- Silicon Carbide Whisker-Reinforced Ceramics

- Sintered Silicon Carbide Used as a Seal Face in Automotive Water Pumps

- AC Electric Drive Train

- Ceramic Material Heat Engine Components

- Nickel Metal Hydride Cells, Modules, and Vehicle Batteries

- Biomass Feedstock Technology

- DYNA3D Finite Element Analysis Technology

- Zymomonas Mobilis Organism

- Lightweight Materials Technology Development

- Industrial Technologies

- Catalytic Distillation

- Ultralight Aerogels

- Aluminum Remelting Technology

- Vacuum Pressure Swing Absorption

- Electrochemical Dezincing of Steel Scrap

a High Efficiency Weld Unit

- Direct Steelmaking

- Superplastic Metal Formation Technology

- Securing Future Energy Supplies

- Renewable Energy

- Photovoltaics 


\section{DISCLAIMER}

This report was prepared as an account of work sponsored by an agency of the United States Government. Neither the United States Government nor any agency thereof, nor any of their employees, make any warranty, express or implied, or assumes any legal liability or responsibility for the accuracy, completeness, or usefulness of any information, apparatus, product, or process disclosed, or represents that its use would not infringe privately owned rights. Reference herein to any specific commercial product, process, or service by trade name, trademark, manufacturer, or otherwise does not necessarily constitute or imply its endorsement, recommendation, or favoring by the United States Government or any agency thereof. The views and opinions of authors expressed herein do not necessarily state or reflect those of the United States Government or any agency thereof. 


\section{DISCLAIMER}

Portions of this document may be illegible in electronic image products. Images are produced from the best available original document. 
- Wind Turbine Technology

- Gas and Oil Exploration and Production Technologies

- Polycrystalline Diamond Drill Bits

- Mudpulse Telemetry for Measurement While Drilling

- Carbon Dioxide Sand Fracture Production Technology

- Hot Oiling Paraffin Treatment

- Insulating Doughnut for Steam Flood of Deeper Oil Wells

- Improved Oil Recovery Technology for the Green River Formation

- Carbon Dioxide Miscible Flooding Technology for Oil Recovery

- Computerized Oil Field Simulators

- Foam Fracturing of Gas Reservoirs

- Enhanced Oil Recovery Predictive Models

- Coal Use Technologies

- Integrated Gasification Combined Cycle

- Super 9 Chrome Alloy

- Atmospheric Fluidized Bed Coal Combustor

- Low Nitrogen Oxide Burner

- Pure Air Scrubber

- Micro-Mag Sulfur Removal Process

- Advanced Instrumentation Development

- Ceramic Composite Filters for Hot Gas Cleanup

- Slagging Advisor Software Model

- Nuclear Fission Technologies

- Light-Water Reactors

- Extended Burnup of Light-Water Reactor Fuel

- Greenhouse Gas Emissions Reduction

- Advanced Light-Water Reactors

- Reduced Enrichment Fuels for Research and Test Reactors

Isotopes

- Radioisotope Thermoelectric Generators

- Advanced Electricity Generation and Storage Technologies

- Phosphoric Acid Fuel Cells

- Advanced Gas Turbine Components

- High Energy Batteries for Consumer Products

\section{Energy Mission}

The Department of Energy's mission and its civilian energy research and development (R\&D) programs are motivated by a number of important and enduring public policy objectives. These objectives are rooted in national security, economic, environmental, and scientific leadership considerations. They reflect the pervasive role that energy plays in modern society. They are underpinned by a respectful understanding of history and of the unique vulnerabilities that our Nation faces with regard to certain aspects of long-term energy supply and end-use.

\section{Role of Federal R\&D}

Accordingly, the Department's applied energy R\&D programs fill an important gap in the United States' $\mathrm{R} \& \mathrm{D}$ continuum. This gap is where it is clearly in the public interest to pursue certain technological opportunities, especially those that are longterm or highrisk, but where for economic reasons it is not in the market's interest to do so. 
The reasons for this gap are many. One is that the public benefits, such as national security or environmental quality, are simply not fully reflected in market prices. Another is that private firms are finding it increasingly difficult to recoup their R\&D costs by appropriating exclusively to themselves the true benefits of the R\&D. In today's highly competitive global market, technical secrets are shortlived and too easily stolen, scientists are hired away, and inventions are slightly modified in order to circumvent intellectual property rights. More fundamentally, the R\&D itself is often too challenging, requiring large interdisciplinary teams of scientists, working year after year on expensive and unique laboratory equipment. Finally, the structure of certain industries is often too fragmented, or the firms too small, to mount the sustained R\&D campaign necessary for success.

Within this context, the proper role for the U.S. Department of Energy's applied R\&D programs is not to subsidize or displace private sector responsibilities for $\mathrm{R} \& \mathrm{D}$, but to complement them selectively in ways that will help achieve important longterm public policy objectives and that are justified by one or more of the special market circumstances outlined above.

\section{What Successes?}

So, after nearly two decades of investing in such R\&D at the U.S. Department of Energy, is it fair to ask "What benefits have accrued to the U.S. economy?"

Yes, it is-and the answer is impressive. Many outputs of the Department's R\&D, conducted in pursuit of its public policy objectives, not only have had substantial economic success in the marketplace, but also have proven to be fundamentally important in one technical area after another in positioning U.S. industry at the forefront of global competition. In today's markets, winning products are often those with technically driven advantages in performance and price, and the Department's R\&D has contributed significantly to many of these winning products.

Among such products is the electronic ballast for fluorescent lighting fixtures that has become the lighting technology-of-choice. It has already saved U.S. electricity consumers $\$ 750$ million, a saving that grows every day. Another technology, low-emissivity window coatings, has gained a 34\% market share of all new double-glazed residential windows.

And, the economic benefits of the Department's programs will continue well into the future. Four technologies in one building technologies $R \& D$ program are expected to net more than $\$ 16$ billion in economic savings to U.S. taxpayers by the year 2015, far outstripping the total past and projected Department of Energy investments in this area of R\&D.

These statistics may surprise some critics of the Department's R\&D programs. Many of the Department's most important R\&D contributions lie in the "precompetitive" stages of technology development, or in important intermediate technology components, and such contributions are often hidden in the final product. Many people might recognize the technological sophistication of modern commercial trucks and diesel engines, Boeing 757 and 767 aircraft, and high-efficiency lights, windows, and appliances; but few would realize that Department of Energy technology is inside those products and is responsible, in part, for their fast-growing global market shares.

To be sure, the Department has embarked on some R\&D activities without yet achieving the desired results, and some of these are highly visible and costly. As with most high-risk ventures, targets cannot always be met, both in private and public sector $R \& D$ programs. The purpose of the Department's $R \& D$ programs is to explore these high-risk technical possibilities.

Many of the bold experiments in energy demonstration projects of the late 1970s, motivated by global 
conflict and national security concerns over oil, are now seen in hindsight as having been too ambitious. Some expensive technology pushes are no longer supported--for example, synthetic fuels, the Clinch River Breeder Reactor, magnetohydrodynamics, and the Stirling automobile engine--because they were not economically successful, even though they produced a wealth of scientific knowledge and engineering experience. But these are only a part of the picture.

\section{Improved R\&D Productivity}

More fundamentally, the Department's record of R\&D productivity has steadily improved over nearly two decades of R\&D investment. Management techniques for R\&D have become more sophisticated and less congressionally directed. They are now squarely rooted in competition, driven by technical merit and scientific peer review, and aligned with the needs of cost-sharing industrial partners.

\section{Economic Successes}

This report compiles a brief list of some of the more significant Department sponsored technology developments that have already had, or will have in the next year or so, significant impacts on the U.S. economy. It omits hundreds of scientifically and technically important developments and focuses only on examples of successes with major economic significance.

As a word of caution, please note that the pathway of scientific discovery, from basic research to product development, is often complex and multifaceted. Bringing a new product to market involves many players, and credit for their existence should be shared broadly. The final stages of development are almost always, as they should be, private sector interests. The products that consumers see rarely have any overt indication of an underlying Federal or Department of Energy R\&D role.

This does not mean, however, that the R\&D was not important, or that it would have been developed anyway if just given enough time. The examples in this report show that the Department of Energy's $R \& D$ programs played a key and enabling role in the resulting technology development. The Department does not claim credit for the final design and production of the commercial products. Nor does it wish to understate the critical importance of the private sector's role. It does want to emphasize, however, the collaborative nature of scientific discovery and technology development, with private and public actors each playing distinct and complementary roles.

\section{R\&D Management Principles}

The Department's programs support high-risk, precompetitive research. The Department's applied energy $R \& D$ investments are guided by a set of $R \& D$ management principles, which limits and carefully guides the use, and guards against the misuse, of public funds for R\&D. The Department supports R\&D if and when serious shortfalls occur in areas of R\&D otherwise important to society.

\section{R\&D Considerations}

The Department of Energy's decisionmaking on investment in R\&D takes into consideration the following factors:

- The overall significance of the potential benefits of the R\&D to the Nation.

- The level of technical difficulty of the task and whether the overall risk of the R\&D is such that private industry will not undertake the development on a timely basis.

- The nature of the R\&D and whether or not an individual firm might recover its research costs by appropriating to itself the benefits of the knowledge (a "public good") it creates.

- The nature of the industry and whether the fragmented structure of an industry might work against sufficient levels of R\&D spending because its firms are too small to undertake certain kinds of R\&D projects. 
- The distance from commercialization, where certain proprietary sensitivities otherwise might adversely affect private sector competition.

\section{Deficit Reduction or Revenue Enhancement?}

Given these considerations, the Department's funding of applied energy R\&D is a wellfounded, complementary public investment in the advancement of science and technology in areas critically important to the Nation's future. Upon this enabling foundation of precompetitive research and knowledge, corporate America can build and market its own commercial products, which is the proper domain of the private sector.

These successes result in new products and processes that compete successfully in global competition and employ U.S. workers in high value-added jobs, who pay taxes on their income. These technologies reduce costs to businesses and consumers, which stimulates the economic growth of the Nation and adds to corporate taxable profits, all of which return revenue to the Treasury.

Accordingly, a case can be made that an investment in the Department's applied energy R\&D programs should not be viewed as a current operating expense on the deficit side of the Federal budget account, but rather as a high-risk portfolio of capital investments in the Nation's future, with a predictable portion resulting in significant economic paybacks that are already adding net revenue to the income side of the Federal ledger. These R\&D investments.not only produce public benefits, but make money for the U.S. Treasury.

\section{Increasing Energy Efficiency}

Energy efficiency improvements in homes, commercial buildings, transportation, and industry can contribute significantly to offsetting increased energy demand while freeing up capital for use elsewhere. Benefits from demand reduction include avoiding costly capital investments in electric capacity, lessening reliance on imported energy supplies, and reducing harmful emissions.

The Department of Energy aims to develop cost-effective energy-efficiency technologies that protect the environment and support the Nation's economic competitiveness. To achieve this goal, the Department emphasizes carefully targeted cost-shared collaborations with public and private enterprises. U.S. industry is increasingly involved in developing and using these technologies, thanks to the efforts of the Department.

Our programs in these areas carry out the Department's responsibility under the Energy Policy Act of 1992 (EPACT) and other major pieces of authorizing legislation. The benefits of the Department's efficiency programs--to industries, homeowners, and commercial firms-can be measured in cost savings, productivity gains, new high-value jobs created, and improved productivity and competitiveness for U.S. industry. The following paragraphs highlight some of the successes that have flowed from these programs.

\section{Building Technologies}

Residential and commercial buildings consume more than one-third of all U.S. primary energy and about two-thirds of the Nation's electricity. To help realize the energy security, economic, and environmental benefits of improved energy efficiency in buildings, the Department supports research and development on building systems, envelope, and equipment.

\section{Fluorescent Lamp Electronic Ballasts}

Department of Energy research and development created the current state-of-the-art electronic fluorescent lighting ballast, which was unknown in the mid1970s. The electronic ballast not only 
improved lighting quality, but has saved consumers $\$ 750$ million in consumer energy bills from a $\$ 3$ million research and development investment. This new industry's sales totalled $\$ 275$ million in 1992 , accounting for 25 percent of total ballast sales. Electronic ballasts are expected to replace magnetic ballasts in at least 75 percent of applications by 2015 .

\section{Advanced Energy Efficient Windows}

A 20-year Department of Energy research and development partnership with industry culminated in the development at Lawrence Berkeley Laboratory of an advanced energy-efficient window that uses low-emissivity coatings to block heat gain or loss. No U.S. manufacturer had invested in this technology before the Department's $R \& D$ investment. Cumulative consumer energy savings attributable to using low-emissivity windows are $\$ 1.8$ billion. This enormous savings was leveraged and catalyzed by a Department of Energy investment of just $\$ 3$ million through the early 1980 s. The Department teamed with five window manufacturers (Andersen, Cardinal IG, OwensCorning Fiberglass, Pella, and Southwall Technologies) and the Bonneville Power Administration to convert the concept into commercial prototypes. Today, every major glass and window manufacturer offers low-emissivity products. Their market share is one-third of all residential windows.

\section{Sulfur Lamp}

In October 1994, the Department of Energy and a small Maryland company, Fusion Lighting Inc., unveiled the sulfur lamp, or S-Lamp, a revolutionary new type of light system in which microwaves are used to heat a sulfur core. The S-Lamp is a scientific and technological breakthrough, considerably more efficient than even fluorescent lights, with fewer associated environmental problems. The quality of light is vastly improved, more nearly approximating natural sunlight, and the installation costs are one-sixth that of conventional lighting. At present, the new system is being demonstrated at the Department's Headquarters, where it lights the outdoor entrance to the building, as well as at the Smithsonian Air and Space Museum. Two S-Lamp bulbs have replaced 240 mercury bulbs, providing four times the light at one-third the cost. Unlike other high efficiency lamps, the Sulfur Lamp uses no mercury and produces 50 percent less ultraviolet light. The United States uses 520 billion kilowatt hours annually for lighting. The S-lamp is expected to have enormous potential commercial and residential applications.

\section{Computerized Analytical Tool for Energy Efficient Building Design}

Department of Energy research and development has created a powerful analytical software tool, DOE-2, for reducing energy use in buildings. DOE-2 calculates hourly building energy use and cost from information on the building's construction, climate, operation, heating, ventilating, and airconditioning systems, and utility rate schedule. At least 5 percent of commercial buildings today are designed with DOE-2. Use of the software accounts for $\$ 1.9$ billion in energy savings for buildings constructed through 1993.

\section{High-Efficiency Refrigerator/Freezer Compressor}

From 1978 through 1980, the Department of Energy, through Oak Ridge National Laboratory, sponsored a contract with Columbus Products Co. to develop a high-efficiency compressor for household refrigerators. The resulting product achieved a $44 \%$ improvement over the compressor technology used in refrigerators at the time. The availability of high-efficiency compressors was a major reason that refrigerator energy use dropped from about 1,300 kilowatthour per year in 1980 to about 900 kilowatthour per year in 1990 . Use of the improved compressors pioneered by this research effort has saved consumers at least \$6 billion in energy costs from 1980 through 1990.

\section{Flame Retention Head Oil Burner}

In the early 1970 s, concern with oil supply and price volatility increased interest in improving the efficiency of oil use. The Department of Energy sponsored field testing by the Oil Heat Research and 
Development Program at Brookhaven National Laboratory, which established the energy conservation benefits of the retention head oil burner. A second Department effort published the findings in a consumer-oriented information booklet. In several years the retention head burner achieved total dominance of the market for new and replacement oil burners. Consumer energy cost savings to date from this innovation total more than $\$ 5$ billion.

\section{Flame Quality Indicator}

The flame quality indicator, developed by the Oil Heat Research and Development Program at Brookhaven National Laboratory, has been called the most significant advance in oil heating technology since the introduction of the flame retention head burner in the 1980s. The flame quality indicator ensures that the burner operates at peak efficiency throughout the year by monitoring the brightness of the oil burner flame and warning the consumer when the burner needs maintenance. From a Department of Energy investment of slightly more than $\$ 1$ million, this technology potentially can reduce oil use by 290 million gallons per year, which represents $\$ 3$ billion to consumers over 10 years. Currently, three licensed manufacturers have entered the market. The flame quality indicator received the 1992 R\&D Magazine R\&D 100 award and the 1993 "Best of What's New" from Popular Science magazine.

\section{Compact Fluorescent Lamps With Convective Venting}

Compact fluorescent lamps produce less light and operate at reduced efficiencies at the elevated temperatures often associated with constricted environments (such as within recessed fixtures). A Department of Energy laboratory has received a 1994 Federal Laboratory Consortium Award for Excellence for developing a convective venting method to alleviate this problem. The cooling action produced by the convective venting yields an approximate 18percent increase in lumen output, while increasing lamp service life from 750 to 10,000 hours. This approach has been adopted by several large fixture manufacturers (Delray Lighting, Lithonia, Kurt Versen, and Prescolite).

\section{Softdesk Energy Building Software}

A collaboration among the Department of Energy, the University of Oregon, and Softdesk, Inc., resulted in Softdesk Energy, a software building design system that incorporates energy-saving features into computer-based building designs. The program integrates specialized software, computer-aided drafting tools, and commonly used manual tools for energy-use estimation. Used during the design process, the one-of-a-kind system provides quick feedback on a building's future energy consumption. The system also determines energy use impacts from internal factors such as lighting, temperature, humidity, ventilation, and building use. Softdesk Energy requires minimal input from the architect, which significantly reduces design time and costs and encourages the exploration of energyefficient building designs. The system is designed and equipped to incorporate other energy design tools such as code and standards compliance, lighting design tools, detailed energy analysis packages, and heating, ventilation, and air-conditioning equipment selection tools. Of 167,000 computer-aided building design users, 100,000 (60 percent) are Softdesk users.

\section{Appliance Efficiency Standards}

The Department of Energy is required by law to set energy-efficiency standards for a number of appliances, including refrigerators and freezers, stoves and ovens, dishwashers, water heaters, and heating and cooling equipment. The Department updates the standards to ensure that models coming onto the market incorporate the best available efficiency technologies. These standards have already saved U.S. consumers nearly $\$ 2$ billion on their energy bills. Consumers save $\$ 2.50$ on energy bills for every extra $\$ 1$ paid to purchase appliances meeting the efficiency standards.

\section{Transportation Technologies}


The U.S. transportation sector is still almost totally dependent on oil, and it consumes more than 60 percent of the oil used in this country. Reducing the Nation's vulnerability to oil disruptions will require major changes in the transportation sector's energy demand patterns. Achieving improvements in air quality is also linked to breakthroughs in transportation propulsion technology, as well as changes in the mix of fuels used for transporting people and freight. To accelerate the introduction of more efficient, less polluting transportation technologies, the Department's activities focus on advanced propulsion systems, improved materials, and cost and performance improvements.

\section{Ceramic Regenerator Matrix/Catalytic Exhaust Converters for Automobiles and HeavyDuty Engines}

The Department of Energy research and development in ceramic turbine and materials programs is spawning an entirely new industry with many spinoff components. As an example, the Department's ceramic regenerator development work provided the technological "roots" for a catalytic converter that is now commonly used to reduce automotive emissions. Current sales of such ceramic components for automobiles are $\$ \mathbf{6 0 0}$ million per year worldwide and are expanding. Other component sales are projected at $\$ 1$ billion and 10,000 jobs for the year 2000. Corning Incorporated holds the largest market share.

\section{Silicon Carbide Whisker-Reinforced Ceramics}

Silicon carbide whisker-reinforced ceramics developed by the Department of Energy have increased machining rates up to 800 percent and have dramatically decreased the frequency of cutting tool replacement. These advantages have allowed the United States to recapture a substantial international market share of the cutting tools industry. This composite material was developed in coordinated Department programs with a 7-year investment of \$3.8 million; worldwide sales now exceed \$30 million.

\section{Sintered Silicon Carbide Used as a Seal Face in Automotive Water Pumps}

The Department of Energy Transportation Materials Technology Program, with the Carborundum Company, has developed an improved sintered silicon carbide (ceramic) seal face for water pumps. These seals are used in 30 percent of new U.S. automobiles--up from 5\% in 1993. Shipments will total 10 million seal faces this year for worldwide markets. A Department of Energy investment in mechanical characterization of approximately $\$ 500,000$ over a 5-year period has resulted in a potential worldwide market for these seals in excess of 65 million units per year.

\section{AC Electric Drive Train}

Under a cost-shared contract with the Department of Energy, the Ford Motor Company and General Electric have developed a new electric drive train. This drive train uses one design for a wide range of production vehicles. This new multivehicle design will reduce consumer costs and allow electric vehicles to enter the market sooner. Ford is testing this technology in 105 Ecostar electric vehicles operating around the country. The California laws mandating zero-emission vehicles will result in approximately $\$ 70$ million in electric vehicle sales in 1998 (the only current solution to the California mandates), growing to $\$ 350$ million by the year 2003. Should the New England states implement the California mandates, the market will grow to at least $\$ 1$ billion by 2003 .

\section{Ceramic Material Heat Engine Components}

High melting temperatures, hardness, light weight, and other properties of ceramic materials promise to enable energy efficiency, emissions reduction, and durability improvements in automobile and truck engines. The Department has worked with industry to develop processes that have improved the properties and reliability of ceramics. In 1983, ceramic heat engine parts repeatedly broke. Ten years and $\$ 109$ million of DOE cost-shared research and development has resulted in U.S. industrial ceramic 
materials that exceed the strength, durability, and reliability requirements for transportation applications. The Department has developed a process, with a U.S. company, to reduce the cost of producing silicon nitride ceramic powder from $\$ 30$ per pound to slightly more than $\$ 10$ per pound. The ultimate goal is $\$ 6$ per pound. Manufacturers are beginning to use this material for a variety of parts in production engines. Allied Signal, for example, is manufacturing ceramic oil pump spacers for use in commercial aircraft, including Boeing, Gulfstream, and Airbus. As another example, more than 15,000 ceramic cotter pins have been sold for aircraft applications.

\section{Nickel Metal Hydride Cells, Modules, and Vehicle Batteries}

Nickel metal hydride batteries are one of three midterm batteries being developed by the Department of Energy through the United States Advanced Battery Consortium. This battery technology is approaching all of the consortium's midterm goals, with the exception of cost. The consortium is now concentrating on developing lower cost materials and improved production processes. Given the performance of this technology, General Motors has formed a joint venture with the Ovonic Battery Company. Replacing the lead acid battery in the General Motors Impact car with this nickel metal hydride battery will increase the range of the vehicle from 70 miles to 140 miles between recharges. A conservative market estimate for this battery, as the result of the mandates for zero emission vehicles in California and the Northeastern States, is approximately $\$ 350$ million in 2003.

\section{Biomass Feedstock Technology}

Hybrid poplar "supertrees," which are being commercially planted by six major pulp and paper companies in the Pacific Northwest, were developed through Department of Energy investment in research programs for producing biofuels feedstocks. This portion of the Department's Biofuels Feedstock Development Program, focused in the Northwest, has invested approximately $\$ 2$ million over 17 years to produce genetically superior trees and improved agricultural production techniques. Acreage planted is expected to double from the 25,000 acres planted now to well over 50,000 acres within the next 2 years. Two mills are already using the fiber to produce paper as well as energy for their boilers, and two new nursery companies have emerged to supply high-quality cuttings to private industry and landowners. The Western Washington plantings established along rivers provide habitat to an endangered deer species and other wildlife. Each acre of hybrid poplars planted displaces the need to harvest 10 acres of Douglas Fir for fiber.

\section{DYNA3D Finite Element Analysis Technology}

The Department of Energy sponsored research that developed DYNA3D, a dynamic finite element analysis tailored to simulate high energy impacts, such as car crashes or aircraft collisions with birds. DYNA3D is available at near-zero cost to the public and has had a major impact on U.S. industry. It is used by more than 300 U.S. companies, including GE Aircraft Engines, General Motors, Chrysler, the Boeing Company, ALCOA, General Atomics, FMC Corporation, and Lockheed Missiles and Space Company. The technology is used by all U.S. car manufacturers and has sharply reduced the need for costly vehicle crash testing. An independent study placed the savings to U.S. industry as a result of using the model at $\$ 350$ million.

\section{Zymomonas Mobilis Organism}

In 1994, research sponsored by the Department of Energy developed a new, genetically engineered organism, Zymomonas mobilis. This organism enhances the fermentation of cellulose, increasing the rate of conversion and yields of ethanol for use as fuel. It is estimated that this new technology, which was described in the prestigious journal, Science, and widely written about by the Associated Press, has significantly reduced the cost of ethanol from $\$ 3.60$ per gallon to less than $\$ 1.00$ per gallon, making ethanol a more competitive alternative fuel. 


\section{Lightweight Materials Technology Development}

Reducing vehicle weight through the use of lightweight materials promises to enable major energy efficiency improvements in fullsize automobiles without compromising passenger comfort and safety. At the program's inception in 1992, lightweight metals such as aluminum could not compete with steel as the material of choice for automotive manufacturing because of their cost and forming time. After three years and $\$ 3$ million of Department of Energy costshared R\&D, advanced forming of aluminum sheets for auto body components achieved weight reductions of 43 percent, parts count reductions of 89 percent, forming time reductions of 77 percent, and cost reductions of 15 percent. Projected cost savings to auto companies are about \$60 million per year by 1997 .

\section{Industrial Technologies}

The Department's industrial energy activities are motivated by energy, economic, and environmental policy objectives. Specific activities are shaped by the recognition that enhanced energy efficiency is a key to increasing industrial productivity and that improving efficiency of industrial energy use is closely linked to reducing waste and pollution. The goal of the industrial energy program is the creation of a more efficient, competitive, environmentally sound, and sustainable domestic industry, and to promote environmental stewardship, competitiveness, and job preservation and creation by demonstrating profitable alternative approaches to regulatory compliance.

The Department collaborates with industry to reduce energy use through new technologies in heat recovery, energy utilization, and industrial and municipal waste management. Other programs develop process improvements and innovations for specific energy-intensive industries such as pulp and paper, steel, and chemicals. In addition, applied research in combustion, biotechnology, advanced materials, and heat transfer will provide the foundation for future advances in technology. An active technology transfer program provides an effective link between the research and development programs and the community of potential users.

More than 50 technologies in the Department of Energy's Industrial Technologies Program are economically successful. An investment in developing these technologies of about $\$ 1.1$ billion from fiscal year 1977 through 1994 has yielded approximately \$2.5 billion in energy savings and capital productivity.

\section{Catalytic Distillation}

The advanced catalytic distillation process developed by the Department of Energy nearly 15 years ago has become a major commercial success. It is used to produce gasoline additives such as methyl-tertiary-butyl-ether and tertiary-amyl-methyl-ether, thus helping U.S. refiners produce the reformulated gasoline mandated by the Clean Air Act Amendments of 1990. As of fiscal year 1994, 80 units were on order at the manufacturer, Chemical Research and Licensing, Inc., 19 units were operating in the United States, and 40 units were operating worldwide--28\% of the world market. Advanced catalytic distillation saved 3.24 trillion British thermal units of energy in 1993 alone, at a rate of about $\$ 10$ million per year.

\section{Ultralight Aerogels}

Scientists sponsored by the Department of Energy at two national laboratories have developed a new material, called aerogel, that has the lowest density, highest porosity, lowest thermal conductivity, and lowest sound propagation of any solid ever made. A 1-inch-thick layer of aerogel replaces 12 inches of fiberglass insulation. This feature is particularly valuable in appliances such as refrigerators and water heaters. While industry interest in better insulation is being explored, the unique properties of aerogel have opened other market opportunities for this emerging technology. Because of their high surface-to-volume ratio, these materials can be used as catalytic and adsorbent surfaces and as carbon 
ultracapacitors. Ultralight aerogels are being taken to the commercial market by Aerojet, a segment of GenCorp.

\begin{abstract}
Aluminum Remelting Technology
A $\$ 400,000$ grant from the Department of Energy, through the National Industrial Competitiveness Through Energy, Economics, and Environment program to AAP St. Mary's of Ohio has resulted in a more efficient technology for aluminum remelting. By avoiding the second aluminum chip melt during recycling, real energy savings are 6.36 billion British thermal units annually--6,249 gallons of diesel fuel, and 155,000 gallons of coolant. Additionally, the new technology eliminates 59 tons per year of emissions and 64 tons per year of dross. Dollar savings equal \$642,000 annually.
\end{abstract}

\title{
Vacuum Pressure Swing Adsorption
}

By eliminating the nitrogen from air in glassmaking furnaces burning gas or oil, vacuum pressure swing adsorption technology has reduced furnace emissions of nitrogen oxides by 90 percent and particulates by 25 percent. Furnace energy requirements are reduced by 25 percent. Three companies, Praxair, Inc., (Tarrytown, N.Y.), Corning, Inc., (Corning, N.Y.), and Gallo Glass Company (Modesto, California) have commercialized this energy-efficient technology. Approximately 15 percent of all glass made in the United States now employs this technology.

\section{Electrochemical Dezincing of Steel Scrap}

Department of Energy scientists have developed an electrochemical method of removing the galvanized coatings from steel scrap that would allow 10 million tons of this valuable resource to be used in steelmaking furnaces. This process would increase production yields and quality as well as decrease environmental problems and cost. By the year 2000, electrochemical dezincing could save 50 trillion British thermal units of energy, reduce raw material costs by at least $\$ 160$ million per year, and reduce the need to import at least 75,000 tons per year of zinc, saving at least $\$ 77$ million annually.

\section{High-Efficiency Weld Unit}

Improving power supply efficiency is key to achieving significant energy savings in welding processes.

Conventional arcwelding power supplies use a low-frequency transformer, which makes them power-inefficient and unwieldy in weight and size. The Department of Energy developed a more efficient power supply with the Cyclomatics Company. The new system uses solidstate electronics known as inverter technology to shut off power to essentially all of the power source components when a unit is idling. This reduces electrical energy consumption by up to 45 percent compared to conventional power supplies. Nationwide, these units have saved more than 13 trillion British thermal units of energy and can be credited with reducing emissions of carbon dioxide by 20,000 tons each year. Annual savings are $\$ 15$ million.

\section{Direct Steelmaking}

The Department of Energy supported post-combustion research in a Basic Oxygen Steelmaking Furnace, which led to the application of the technology in the electric arc furnace. The result is a savings of 40 to 50 kilowatthour per ton and a 6 to 7 percent increase in productivity. This work was performed by Union Carbide, now Praxair, under a subcontract from the American Iron and Steel Institute. Praxair is now marketing the technology worldwide. This technology can be applied in approximately 50 million tons of steelmaking annually, with an annual savings of $\$ 30$ million.

\section{Superplastic Metal Formation Technology}

The superplastic metal forming process developed through research sponsored by the Department of Energy allows the manufacture of metal components into shapes very near final dimension. This results in several advantages. It minimizes machining material waste, eliminates the use of environmentally 
damaging solvents, and saves energy, time, and labor costs. Further, it allows the use of new materials such as lightweight alloys, and enhances design freedom by creating the opportunity to produce unique complex shapes. Manufacturers report a 20 percent savings in metal machining processes

\section{Securing Future Energy Supplies}

Today more than 85 percent of the useful energy and power produced in the United States comes from boilers, furnaces, and internal combustion engines that rely on fossil fuels. The Nation's increasing dependence on imported oil makes us vulnerable to supply disruptions and related price shocks. Although natural gas and coal are mostly domestic fuels, the heavy reliance on fossil fuels necessitates costly efforts to control pollution. Improving the Nation's ability to develop cleaner technologies and secure future energy supplies is vital to our economic, environmental, and social well-being.

The Department of Energy seeks to achieve this goal by research and applied technology development aimed at diversifying energy sources--especially promoting increased use of indigenous resources, including oil, gas, coal, nuclear, and renewable energy. We also support efforts to increase the efficiency of electric energy distribution and storage. To better ensure early commercial application of successful technologies, this research and development will be based on cost-shared joint government-industry-university collaborations wherever possible. Some success stories on the supply side of the energy ledger are highlighted in the following paragraphs.

\section{Renewable Energy}

The Department supports a balanced development and deployment effort on promising renewable energy technologies aimed at increasing the production and use of domestic energy resources, and is working with industry to strengthen the technology base leading to new products and processes for the commercial market. The number of private-sector partners willing to cost-share key research projects is evidence that the private sector has a legitimate interest in these technologies. Research and development on photovoltaics, solar thermal, wind, biomass, and geothermal energy will help strengthen the Nation's energy security, promote sustainable energy approaches, and increase U.S. industrial competitiveness. The goal in this program area is to triple the U.S. nonhydropower renewable energy capacity by the year 2000 .

Continued cost reductions fostered by our strategic research, development, and deployment activities can ensure the United States a place in an emerging multi-billion-dollar clean energy market. The establishment of footholds by U.S. based firms in international sales activity is clearly vital. Currently, U.S. photovoltaic and geothermal companies are worldwide leaders as a result of Department of Energy investments in advanced technology development. More than 70 percent of U.S. photovoltaic manufacturing output is exported, resulting in more than $\mathbf{\$ 9 0}$ million in annual revenues. U.S. companies have installed more than 1,000 megawatts of geothermal facilities in other countries and have orders for an additional 2,000 megawatts, creating an annual income stream of \$250 million.

\section{Photovoltaics}

Research and development supported by the Department of Energy has been instrumental in the discovery, synthesis, and development of state-of-the-art semiconducting and photonic materials and devices. Photovoltaic technology converts photons (light) into electricity. Today photovoltaic cells power a wide variety of devices, including spacecraft, watches, calculators, highway signs, navigational aids, emergency telephones, and relay stations; in developing countries, photovoltaic cells power entire remote villages. Photovoltaic systems are an ideal, environmentally sensitive technology for bringing people in remote sites such basic services and amenities as light, water, communications, power for businesses, and power for other productive uses. 
Photovoltaic electricity costs dropped from 90 cents per kilowatthour in 1980 to 20 cents per kilowatthour today. Since 1988, photovoltaic output has doubled; photovoltaic output increased another 24 percent just from 1993 to 1994 . Maintaining and expanding this phenomenal growth depends on continuous improvements in the performance and cost-competitiveness of photovoltaic products, supported through cost-shared R\&D between industry and the Department of Energy. At present, every $\$ 100$ million in direct module photovoltaic sales helps support or create $\mathbf{3 , 8 0 0} \mathrm{U}$.S. jobs.

\section{Wind Turbine Technology}

Collaborative Department of Energy and industry research and development has created today's modern wind turbines, which are already providing sufficient electricity for 1 million Americans. Costs have been reduced from almost $\$ .25$ per kilowatthour in 1980 to the current range of $\$ .05$ to $\$ .07$ per kilowatthour in locations with good wind resources. New wind turbine blades, advanced materials development, and developments in airfoil technology are expected to further reduce the cost of wind-generated electricity to $\$ .04$ per kilowatthour by 2000 . In California alone, there are more than 1,700 megawatts of generating capacity. California's wind powerplants currently provide up to 8 percent of Pacific Gas and Electric's load and save the energy equivalent of 4.4 million barrels of oil each year while producing no air pollution. (In fact, wind power prevents the creation of 2.5 million tons of carbon dioxide and 15,000 tons of other pollutants per year.

\section{Wind Energy Analysis Systems}

A team of scientists at a Department of Energy laboratory produced and documented the most comprehensive analyses available of wind energy resources and wind electric potential in the United States. These analyses are used by utilities, energy planners, and industry. Team members also combined their skills to develop a measurement and analysis system for characterizing turbulence in the wind inflow to a turbine rotor. Efforts are now being extended across the globe to assist developing countries in establishing local wind energy projects. Data derived from the research also convinced the World Bank to include wind power as a viable option for a $\$ 600$ million rural clectrification project in Indonesia. This investment directly serves the Department of Energy missions of pollution prevention and increased energy efficiency.

\section{Geothermal Technologies}

The commercially operated geothermal site at The Geysers in northern California reached peak electric power output of 2,000 megawatts in 1988. Inexplicably, a steady decline in output began in 1989. In 1990, a concerned geothermal industry asked the Department of Energy for assistance in determining the cause. Failure of power production at The Geysers would have a depressing effect on all potential markets for geothermal power. During fiscal years 1990 through 1994, the Department of Energy shared costs with a coalition of geothermal operators and made available both experts and expertise to help diagnose the problem. The cause proved to be reservoir fluid depletion, the result of inadequate reinjection practices and insufficient knowledge of reservoir management requirements. The lessons learned in this effort will continue to benefit geothermal reservoir development for years to come. With a $\$ 12$ million Department of Energy investment--matched by $\$ 42$ million from industry--a potential crisis for hydrothermal energy systems was overcome, reservoir practices leading to decades of stable operation were developed, and more than 300 jobs were directly preserved.

\section{Gas and Oil Exploration and Production Technologies}

Oil remains one of our Nation's vital commodities, supplying 40 percent of the United States' primary energy needs and nearly all of its transportation fuel. Domestic production, however, continues to decline, with two-thirds of all the oil ever found in the United States remaining unrecoverable by conventional production methods. Moreover, the United States has technically recoverable reserves of 113 billion barrels, almost 6 times today's proved reserves. In addition, as much as 1,300 trillion cubic 
feet of natural gas is technically recoverable in the lower 48 States--about 8 times more than current proved reserves. To realize the potential of these oil and gas resources requires continued development of advanced exploration and extraction technologies. The Department is working with industry to develop advanced computing technologies to improve drilling success rates, rock drilling systems for natural gas, and advanced oil recovery technologies, as well as carrying out related research and analytical activities. By enhancing the efficiency and competitiveness of U.S. industry, these research and development efforts will increase domestic energy production, reduce dependence on imports, and create jobs.

\section{Polycrystalline Diamond Drill Bits}

Research and development sponsored by the Department of Energy produced one of the most important advances in drilling technology, a new drill bit design that uses polycrystalline diamond cutters. Previous diamond cutting bits failed when the cutting assembly would break away from the bit after prolonged drilling. This technology, which was spawned by Defense Programs basic research at Sandia National Laboratories, permanently bonds the cutters to the bit. In timecritical drilling situations, this drill bit can save as much as $\$ 1$ million per well. Worldwide, 13 companies now fabricate this synthetic diamond drill bit. U.S. companies produce approximately 4,000 bits per year.

\section{Mudpulse Telemetry for Measurement While Drilling}

One of the most important timesaving innovations used today in the drilling industry is the "measurement-while-drilling" instrument. Before its invention, operators needing to determine drill bit direction had to cease drilling, remove hundreds or thousands of feet of drill pipe, and lower an instrument into the well. Readings would then be taken, the instrument retrieved, and drilling would recommence. In the 1970s, the Department of Energy helped Teleco, Inc., pioneer a wireless system that could transmit the location of a drill bit by sending pressure pulses through the drilling mud that circulated from the bit face to the surface. Today, mudpulse telemetry has gained wide acceptance in the drilling industry and is estimated to have saved the natural gas and oil industry at least \$1 billion over the past 20 years.

\section{Carbon Dioxide Sand Fracture Production Technology}

The Department of Energy's Morgantown Energy Technology Center developed, tested, and helped commercialize this technology for stimulating production from natural gas wells. A nondamaging treatment process, it won the natural gas industry's 1994 Best Technology in the Northeast Award. Of special importance to small, independent producers, the technology has been shown to increase production by 200 to 500 percent. At $\$ 2.00$ per thousand cubic feet, a 3 to 9 million cubic foot well using carbon dioxide sand fracturing will generate $\$ 20$ million more revenue over its productive life.

\section{Hot Oiling Paraffin Treatment}

Buildup of paraffin in the wellbore and near-wellbore formation can cause severe reductions in production of waxy crudes and result in lifting equipment failures. Traditional batch treatments are expensive and can result in formation damage if sound hot oiling practices are not followed, that is, if melted paraffin solidifies before it reaches the bottom of the well and plugs the formation. The Department of Energy developed a computer model that optimizes hot oiling paraffin treatments and aids in determining good practices. The use of this software, to estimate downhole temperatures and effectiveness of hot oiling, helps both producers (especially independents) and service companies by reducing operating and maintenance costs. For example, application of the software by an independent producer in a West Texas field increased the efficiency of production equipment, reduced equipment failures, and resulted in about $\$ 1.00$ per barrel-equivalent reduction in average lifting cost. Industrywide use of the software and good hot oiling practices could result in more than $\mathbf{\$ 1 5 0}$ million per year in reduced operating cost, and also reduce well abandonments. 


\section{Insulating Doughnut for Steam Flood of Deeper Oil Wells}

Steam injected into deeper heavyoil wells can lose significant amounts of heat during the trip from the surface to the reservoir. In fact, a phenomenon known as wellbore refluxing can result in up to six times the heat loss in an uninsulated tubing string than would be normally expected. Sandia National Laboratories, working under a Department of Energy program, devised a 2-inch-long "doughnut" of plastic insulation that, when inserted in the standard tubing coupling, prevents steam from contacting the thin outer coupling walls. Heat loss through refluxing is reduced substantially. This simple device is now standard in the industry, and the savings to the industry will amount to hundreds of millions of dollars over the next decade.

\section{Improved Oil Recovery Technology for the Green River Formation}

An oil recovery field demonstration program cosponsored by the Department of Energy has shown that by properly applying improved waterflooding technology in the Uinta Basin in Utah's Green River Formation, additional oil can be produced from fields that might otherwise have been abandoned. The Department's test has turned around conventional thinking in the region, giving Utah producers a technology that was previously thought to be unusable in the region's complex geology. The initial field test has already added 2.4 million barrels of producible oil to the region's reserves. More importantly, neighboring operators have begun using the technology and will return more than $\$ 160$ million in Federal taxes and royalties, well above the $\$ 112$ million Federal investment to date. Ultimately, recoverable oil reserves in Utah could be expanded by 3.5 billion barrels because of the Department of Energy costshared project.

\section{Carbon Dioxide Miscible Flooding Technology for Oil Recovery}

Three percent of all domestic crude oil (about 180,000 barrels per day) is produced by injecting carbon dioxide into aging reservoirs to force out oil that conventional production techniques cannot recover. The gas mixes with some of the remaining oil in the reservoir, and creates a miscible bank of fluid that pushes additional oil to production wells. In large part, industry gained confidence in carbon dioxide flooding technology through a series of eight field tests conducted in the 1970s and co-financed by oil companies and the Department of Energy and its predecessors. Because of the success of carbon dioxide-enhanced oil recovery, carbon dioxide pipelines have been built throughout west Texas and eastern New Mexico, the principal regions of successful carbon dioxide miscible flooding. With the completion of the LaBarge pipeline, carbon dioxide-enhanced recovery has also been extended to oil fields in Wyoming and could reach others in North Dakota. Today, roughly 68,000 Americans are employed directly and indirectly because of this oil recovery technology. Moreover, data developed through the Department's laboratory research has saved the domestic oil producers at least $\$ 10$ million by allowing them to accelerate development of other recovery processes.

\section{Computerized Oil Field Simulators}

Closely related to predictive models is a family of oil field simulation software developed by the Department of Energy. BOAST (Black Oil Applied Simulation Tool) was introduced in 1982 as a way to simulate the movement of oil, gas, and water through an oil reservoir. BOAST has been upgraded to operate on personal computers and expanded to assess larger areas, larger numbers of wells, and more solution options. More than 2,400 copies of BOAST PC software have been distributed by the Department. Several oil industry consulting firms have modified the program to their own specifications. More than 20 million barrels of oil have been produced as a result of using these simulators, and the return to the taxpayer is more than $\mathbf{\$ 1 , 0 0 0}$ for each $\$ 1$ of Department of Energy investment. Universities are also using BOAST as a textbook for reservoir simulation instruction. A second simulator, UTCHEM, has been developed specifically for chemical flooding. The simulator is being used by approximately 20 oil companies to project the behavior of tracers, polymers, polymer gels, surfactants, and alkaline agents injected into oil reservoirs. Better management of reservoirs has saved 
these companies more than $\$ 23$ million, $\$ 8$ million of which will flow back to the U.S. Treasury. The Department developed a third simulator, MASTER, to assist the natural gas industry in evaluating miscible and nonmiscible gas-enhanced oil recovery processes. By 1994, more than 250 copies of the software package had been distributed. Studies indicate that use of these processes will generate a 3-billion barrel increase in potential reserves.

\section{Foam Fracturing of Gas Reservoirs}

Another technique for creating fractures in a gas reservoir is to inject foam under high pressure into the wellbore. Foam has an advantage over high pressure water injection because it does not create as much damage to the formation, and well cleanup operations are less costly. Before the mid1970s, use of foam fracturing was limited almost exclusively to Canada and the Rocky Mountain region. The Department's research in the late 1970s extended the technology to the Eastern region of the country, where effective fracturing is required to produce commercial quantities of gas from shale formations. More than 50 stimulation tests were conducted to apprise oil and gas operators in 8 Eastern States of the technique's merit. Once it was shown that the process accelerates the rate of natural gas production from these wells by nearly 200 percent, the foam fracture process became the dominant stimulation technique for marginal gas wells in the United States.

\section{Enhanced Oil Recovery Predictive Models}

The Department of Energy, in partnership with the National Petroleum Council and Software/Intercomp, has developed easy-to-use, predictive computer models for numerous enhanced oil recovery techniques. More than 1,000 copies of the PC-based predictive models have been distributed to oil field operators, drilling and service companies, consultants, researchers, and several major oil companies. The use of these models has saved the industry $\$ \mathbf{4 0 0}$ million by screening out uneconomical projects.

\section{Coal Use Technologies}

Coal is the Nation's most abundant fossil fuel and is currently used to generate 57 percent of U.S. electric power. With coal projected to remain a dominant fuel for the power industry for many years, cleaner and more efficient coal-based technologies are becoming increasingly important for the Nation's energy and economic future. Working in close collaboration with industry, the Department's research and development efforts focus on improving the environmental acceptability of coal. These include developing technologies to burn coal more cleanly and efficiently, as well as technologies that can reduce the costs of producing liquid transportation fuels from coal.

\section{Integrated Gasification Combined Cycle}

Capitalizing on a successful gasification program, the Department of Energy has provided the foundation for an advanced power generation system that will be the powerplant of the 21 st century. Advanced integrated gasification combined cycle (IGCC) technology will have system efficiencies ranging from 41 to 52 percent. Emissions of sulfur dioxide and nitrous oxide are limited to less than one-tenth of that allowed by New Source Performance Standards, carbon dioxide emissions are reduced by 35 to 45 percent, and solid waste is reduced by 40 to 50 percent. The IGCC powerplant is cost-competitive to build, in fact it is projected to be significantly less costly than conventional powerplants, while the cost of production would be reduced by 10 to 20 percent. At present, the Department's Clean Coal Technology program will provide the IGCC system entry into the global market as a top-ranking clean coal power generation technology with a potential global market of more than $\$ \mathbf{4 0 0}$ billion in capital investment by 2030 , and about $\$ 150$ billion in the domestic market.

\section{Super 9 Chrome Alloy}

During the 1980s, Department of Energy research and development was instrumental in the development of a superstrong alloy called Super 9 Chrome, which is now used worldwide as an industry standard for 
improving the safety and reliability of equipment in coal-fired powerplants. This 9 percent chromium and 1 percent molybdenum alloy improves the life and performance of equipment under the severe operating temperature, pressure, and corrosion conditions typical of fossil fuel plants. Department of Energy scientists received the prestigious R\&D 100 Award for this technology, which has since been incorporated into American Society of Mechanical Engineers Boiler and Pressure codes and transferred directly to industry for commercial applications. Sales of this product exceed $\$ \mathbf{1 0 0}$ million to date. Use of this alloy has enabled an increase in coal-fired powerplant efficiency of more than 3 percent, which results in a savings of more than $\$ 1.7$ million per year in fuel costs in a typical $500 \mathrm{MW}$ powerplant. The higher efficiency also results in reduced emissions of sulfur dioxide, nitrogen oxides, and particulates, as well as reduced production of carbon dioxide by 280,000 tons per year.

\section{Atmospheric Fluidized Bed Coal Combustor}

The most significant advance in coal-fired boiler technology in more than half a century, the Fluidized Bed Coal Combustor has been the commercial success story of the last decade in the power generation business. This state-of-the-art, low-polluting combustion system technology has progressed into even larger scale utility applications. To date, more than $\$ 6$ billion in domestic sales and \$2 billion in

foreign sales have been achieved through this Department of Energy investment. Domestic sales alone translate into nearly 250,000 jobs. Every major U.S. boiler manufacturer now offers a fluidized bed combustor in its product line.

\section{Low Nitrogen Oxide Burner}

With nitrogen oxides targeted for reduction by the 1990 Clean Air Act Amendments, Low Nitrogen Oxide Burner technology developed by the Department of Energy and Altex Technologies Company has rapidly found its way into the power market. Domestic sales to date total more than $\$ 250$ million, supporting 1,800 U.S. jobs. For wall-fired boilers, nitrogen oxide reduction levels of 35 to 40 percent are achieved at a capital cost of about $\$ 20$ per kilowatthour and a levelized cost of about $\$ 280$ per ton of nitrogen oxide removed. For tangentially fired boilers, the same degree of nitrogen oxide reduction is achieved at a capital cost of $\$ 15$ to $\$ 20$ per kilowatthour and a levelized cost of $\$ 220$ to $\$ 350$ per ton of nitrogen oxide removed. These costs are significantly lower than other options.

\section{Pure Air Scrubber}

The first utility in the United States to meet new Clean Air Act standards for sulfur dioxide control did so using an advanced technology supported by the Department of Energy, the Pure Air Scrubber. The capital cost per unit was half of previous air scrubbers, and it produces a commercially marketable gypsum material, rather than the waste sludge commonly produced by older scrubbers (which causes landfill problems). In one year, the Pure Air Scrubber is eliminating 50,000 tons of sulfur dioxide emissions, turning an air pollutant into enough wallboard to construct nearly 19,000 homes. The project earned Power Magazine's 1993 "Power Plant of the Year" award.

\section{MicroMag Sulfur Removal Process}

Application of the MicroMag sulfur removal process removes 80 percent or more mineral-bound sulfur in coal. Scientists supported by the Department of Energy received a Federal Laboratory Consortium annual award for excellence for developing and transferring this technology to the private sector. This technology is central to a $\$ \mathbf{9 0 0}$ million coal preparation and slurry pipeline energy project in China. The China project alone, developed by Custom Coals Corporation, will support 6,300 U.S. jobs.

\section{Advanced Instrumentation Development}

The Department of Energy's advanced instrumentation development efforts have generated and contributed to several commercial businesses, while fulfilling its role of supporting advanced and conventional power systems. The instrumentation developed in this program includes novel elemental 
analyzers, combustion turbine flame monitors, a steam quality monitor for advanced heat exchanger applications, and an online, real-time particle counter. The instrumentation applications range from optimizing environmental performance to process monitors for reduction of off-specification operations. The commercial value of the instrumentation installed in current operating plants exceeds $\$ \mathbf{4 0}$ million.

\section{Ceramic Composite Filters for Hot Gas Cleanup}

The Department of Energy developed a process that produces continuous fiber ceramic composite filters that will reduce tons of pollutants and save millions of dollars in cleanup costs at hundreds of fossil fuel powerplants across the U.S and elsewhere. Subsequently, Department of Energy scientists developed a chemical vapor infiltration and deposition process to produce filters many more times more resistant to thermal and mechanical shock than conventional filters. $3 \mathrm{M}$ is now beginning to market the filter technology worldwide. The annual market share for the filters is estimated to be $\$ 200$ million per year.

\section{Slagging Advisor Software Model}

The Slagging Advisor Software Model, the result of an industry, university, and Department of Energy team in laboratory coal science, is being marketed worldwide by PSI Powerserve. By optimizing control of boiler fouling, the software improves efficiency and cost in both conventional and advanced systems. Potential industrywide savings are hundreds of millions per year. For example, the software has saved more than $\$ 1$ million annually for one utility alone.

\section{Nuclear Fission Technologies}

Nuclear energy currently provides approximately 20 percent of the electricity supply of the United States. Maintaining nuclear energy as an option to meet the Nation's growing demand for energy is one objective of the Department of Energy. Nuclear energy can provide a secure and clean domestic source of energy generation without emissions of greenhouse gases or acid rain precursors. Conducted in cooperation with the electric utility and nuclear industries, the Department's civilian nuclear energy program is focused on advanced lightwater reactors that are expected to be safer, more reliable, and less expensive than current-generation nuclear energy plants. By working toward making standardized, certified, advanced light-water-reactor designs available before the end of the 1990s, the Department will help ensure that nuclear energy remains an option for the Nation's energy supply in the 21 st century.

\section{Light-Water Reactors}

Although the bulk of the Department of Energy's work on light-water reactors was conducted over many decades, including the 1950s and 1960s, the Department continued to research important refinements in the 1970s and 1980s to improve safety and reduce costs. Based upon Department of Energy research and development in nuclear physics, reactor engineering, and related materials development, there are currently 109 nuclear powerplants (about 100 gigawatts-electric) with full power operating licenses. These powerplants produce approximately 22 percent of the Nation's electricity. The electrical power produced by these plants, if replaced by conventional powerplants, is equivalent to $\$ 20$ billion per year. Over the past 20 years, these plants have replaced the equivalent of $\$ 400$ billion in fossil power, displacing significant amounts of air pollution. Additional Department of Energy research in partnership with the nuclear industry is leading to procedures to extend the life of existing plants. Estimated savings in energy costs for 20 -year life-extension versus replacement is $\$ 800$ million per plant.

\section{Extended Burnup of Light-Water Reactor Fuel}

By 1985, a 10-year research and development partnership between the Department of Energy and the nuclear fuel industry had provided the technology for an approximate 50 percent increase in the burnup (or energy extraction) achieved by each unit of nuclear fuel. This technology is being implemented in operating water-cooled reactors worldwide, yielding fuel cost savings of several million dollars per 
year for each operating reactor, reducing the amount of spent fuel to be disposed of by approximately one-third, and serving U.S. nonproliferation policy interests by making the reprocessing of such spent fuel even more uneconomical.

\section{Greenhouse Gas Emissions Reduction}

Department of Energy nuclear research has resulted in 92 percent of all carbon dioxide emission reductions realized in the electric utility sector since 1973 , avoiding 1,615 million metric tons of carbon emissions. Also, nuclear energy has mitigated 27 million tons of nitrogen oxide and 65 million tons of sulfur dioxide emissions in the United States alone. Internationally, emissions avoided from 1973 through 1991 through the use of U.S. nuclear energy technology is 4,300 million metric tons of carbon dioxide, 70 million tons of nitrogen oxide, and 160 million tons of sulfur dioxide.

\section{Advanced Light-Water Reactors}

The Department of Energy supports research and development to make the next generation of nuclear powerplants, certified advanced light-water reactors, available at the earliest possible date to the marketplace, to ensure the light water reactor is an option in contributing to the new electrical energy capacity required by 2010. In 1994, Final Design Approval, a major milestone toward certification, was achieved for two 1,350 megawatt evolutionary advanced light-water reactor designs. The Senate noted this success in its report on the Energy and Water Appropriation Bill of 1995. Building on research and development sponsored by the Department, the General Electric Company recently sold two advanced boiling water reactor plants to Tokyo Electric Power Company, kicking off sales of the next generation in advanced lightwater reactors.

\section{Reduced Enrichment Fuels for Research and Test Reactors}

During the 1980s, the Department of Energy's Reduced Enrichment Research and Test Reactor Program at Argonne National Laboratory developed and qualified a high-density dispersion fuel that serves U.S. nonproliferation policy interests by significantly decreasing the amount of weapons grade uranium being used for civil programs throughout the world. The Uranium silicide dispersion fuel has received the Innovation Research 100 award (1985), has been accepted by all major research reactor regulatory authorities, and is currently being manufactured commercially in the United States, France, and Denmark. Additionally, fuel fabricators in Canada, Indonesia, and the United Kingdom are in the process of adopting the Uranium silicide fuel. Through 1994, seven foreign and seven U.S. reactors have converted or begun to convert to this low-enriched fuel. Ten other reactors were converted to low enrichment uranium using lower density fuels also developed by the program.

\section{Isotopes}

As a direct result of energy research, Department of Energy national laboratories have been producing and distributing isotopes and isotope services and meeting national isotope needs in nuclear medicine, industrial, and research applications for nearly 50 years. Continued domestic isotope production and its ongoing transfer to private industry fulfills a vital national need. In the United States, isotopes are used in 36,000 diagnostic procedures and 50,000 therapeutic applications daily, with more than 30 million medical uses valued at $\$ 7$ billion to $\$ 10$ billion each year. One promising new medical therapy uses Yttrium-90, currently supplied to several major U.S. cancer treatment institutions. The precommercial research and development success of Yttrium-90 cancer therapy has interested a number of commercial pharmaceutical companies. Savings to U.S. patients could approach hundreds of millions of dollars in improved cancer treatment. The Yttrium-90 is obtained from Strontium-90, a nuclear waste product. 
The Department of Energy has developed and provided radioisotope thermoelectric generators (RTGs) to power spacecraft used in the exploration of outer space ( 24 missions) for more than 30 years. These deep space missions would not have been possible without the RTGs. RTGs convert heat from the radioactive decay of plutonium-238 directly into electricity. They are powering experiments left on the moon by Apollo astronauts, as well as experiments on Mars. The RTGs provide the enabling power for the Pioneer and Voyager spacecraft that have studied Jupiter, Saturn, and Neptune and continue to send back data from beyond our solar system. RTGs power the Galileo spacecraft that is on its way to orbit Jupiter and that provided pictures of the recent Levy-Shoemaker comet impact. RTGs also power the Ulysses spacecraft that is the first such craft to study the polar regions of the Sun. By powering NASA spacecraft, RTGs have made a major contribution to our knowledge of the universe.

\section{Advanced Electricity Generation and Storage Technologies}

The convenience and flexibility of electric power have made this energy form a basic component of our economy and way of life. As previously discussed, the Department of Energy supports R\&D activities that focus on improving the economics, environmental acceptability, and efficiency of conventional and emerging technologies. But in addition, the Department has been actively working on a variety of advanced electric technologies, some of which do not fit neatly into specific program areas.

For example, the Department's Office of Fossil Energy and Office of Energy Efficiency and Renewable Energy have been working with industry on an accelerated program to develop advanced gas-fired turbine systems and fuel cell systems. The new generation of electric power generating systems are expected to have environmental performances and fuel-to-electricity efficiencies that are much improved over today's conventional technologies. Other crosscutting technological areas include large and small-scale electricity-storage technologies.

\section{Phosphoric Acid Fuel Cells}

A Federal investment in the 1980s and early 1990s yielded a radically new approach for commercial power generation, the fuel cell, and positioned the United States as the world leader in fuel cell technology. Relying on electro-chemistry rather than combustion, the fuel cell is attractive for both heavily polluted urban areas and remote applications.

The phosphoric acid fuel cell was the first technology to emerge from one joint public-private, cost-shared program sponsored by the Department of Energy. Seventy-five 200-kilowatt commercial onsite cogeneration systems have been sold throughout the world, including 31 in the United States, by International Fuel Cells Corporation of South Windsor, Connecticut. One of these fuel cells, operated by Southern California Gas, set a record last year for uninterrupted operation at more than 80 percent efficiency. Phosphoric acid fuel cells have also been successfully developed by the Department for transportation applications. A fuel-cell-powered bus, now undergoing field testing, demonstrates significant energy benefits (twice the fuel economy of comparable diesel buses) and environmental benefits (emissions reduced by more than 99 percent compared to diesel buses). The projected annual sales of fuel cell technologies could total more than $\$ 1$ billion by 2020, a market that could create as many as 100,000 U.S. jobs.

\section{Advanced Gas Turbine Components}

The Department of Energy is cost-sharing an 8-year development program to produce a leapfrog advanced gas turbine technology that will ensure continued U.S. leadership in the global market. While the entire turbine system will not be completed until the year 2000, key components have already emerged from the development effort and are being used in commercial turbines. In late 1994, Westinghouse Corporation announced a new type of industrial gas turbine, the $501 \mathrm{G}$, the most fuel-efficient machine in its class. Advanced technology from the Department's R\&D program is 
incorporated into the turbine. Closed-loop steam cooling of blades and rotors, techniques developed in the joint government-industry program, have effectively eliminated efficiency losses caused by earlier methods of air cooling. Although the United States dominates the global turbine market, foreign vendors are closing the gap. The leapfrog turbine emerging from the Department's program is expected to maintain U.S. dominance in a multibillion dollar world market.

\section{High Energy Batteries for Consumer Products}

Investigations supported by the Department of Energy of nonaqueous electrolytes such as propylene carbonate provided the fundamental information needed to develop batteries based on electrolytes. High-energy primary (nonrechargeable) lithium batteries, which were not available prior to this research, are now in widespread commercial use. New generations of these electrolytes are also employed in secondary (rechargeable) lithium batteries now under development and in early stages of

commercialization. The commercial use of such high-energy batteries has accompanied and enabled the explosive growth of the multibilliondollar portable electronics industry, which includes laptop computers and portable tools. The technology can also be used in home and auto security systems, electronic tools, robotics, and medical instruments. 